\title{
STUDI EKSPERIMENTAL DAN ANALITIS KAPASITAS SAMBUNGAN BAJA BATANG TARIK DENGAN TIPE KEGAGALAN GESER BAUT
}

\author{
Noek Sulandari, Roi Milyardi, Yosafat Aji Pranata \\ Program Studi Teknik Sipil, Fakultas Teknik, Universitas Kristen Maranatha \\ Jalan Prof. drg. Suria Sumantri, MPH. No. 65 Bandung 40164 \\ Email: noek.sulandari@eng.maranatha.edu,roi.milyardi@maranatha.edu,yosafat.ap@gmail.com
}

\begin{abstract}
ABSTRAK
Sambungan baut pada batang tarik baja memiliki kapasitas dengan macam-macam tipe kegagalan. Kapasitas sambungan baut pada batang tarik baja dapat ditentukan melalui analisis kapasitas dan kegagalan sambungan. Pada analisis kapasitas dan kegagalan sambungan batang tarik baja, kapasitas sambungan batang tarik baja yang ditentukan dihasilkan berdasarkan banyak parameter struktur diantaranya profil dan mutu batang tarik, tebal dan mutu pelat penyambung, dan juga tebal dan mutu baut sambungan. Kapasitas sambungan batang tarik baja hasil analisis kapasitas dan kegagalan sambungan seringkali memiliki nilai yang lebih rendah dari kapasitas sambungan dalam kondisi riil. Pada penelitian ini dilakukan perbandingan kapasitas sambungan batang tarik profil siku 30x30x3mm bermutu BJ-37 disambung dengan pelat mutu BJ-37 tebal $3 \mathrm{~mm}$ dan baut penyambung diameter $8 \mathrm{~mm}$ dengan mutu A307 melalui studi analisis kapasitas dan kegagalan dan studi eksperimental dengan tipe kegagalan geser. Pada studi analisis kapasitas dan kegagalan sambungan batang tarik baja diperoleh kapasitas sambungan sebesar 18,9 kN dengan tipe kegagalan geser. Pada studi eksperimental dilakukan pengujian tarik sambungan baja batang tarik dengan 3 buah benda uji, didapatkan nilai rata-rata kapasitas ultimit sebesar 22,63 kN dan mengalami kegagalan geser baut pada ketiga benda uji. Kesimpulan yang dapat diambil dari penelitian ini adalah baik hasil perhitungan secara analitis dan pengujian eksperimental di laboratorium menunjukkan trend yang baik dan sama. Benda uji didesain berdasarkan perhitungan analitis untuk mengalami kegagalan geser pada baut, hasil pengujian eksperimental untuk 3 (tiga) benda uji seluruhnya menunjukkan pola kegagalan geser baut. Kekuatan nominal tarik rencana $\left(\mathrm{R}_{\mathrm{n}}\right)$ dari hasil studi analitis dengan beban ultimit hasil studi eksperimental memiliki perbedaan sebesar 16,48 \% dengan hasil eksperimental lebih tinggi. Melalui penelitian ini diharapkan dapat menjadi media pembelajaran untuk mengetahui salah satu jenis kegagalan pada sambungan batang tarik yaitu kegagalan geser baut, memperoleh gambaran perbandingan hasil perhitungan analtis yang mengacu pada standar perencanaan yang berlaku serta hasil pengujian eksperimental di laboratorium.
\end{abstract}

Kata kunci: Sambungan Batang Tarik Baja, Kegagalan Geser, Eksperimental, Analitis, Kapasitas.

\section{ABSTRACT}

The bolted connection of the tension steel rod has capacity with various types of failure. The capacity of the bolted connection on the steel rod can be determined through capacity analysis and connection failure. In the capacity analysis and failure of steel tensile connection, the specified tensile connection capacity is generated based on many structural parameters such as the cross-section and quality of the tensile rod, the thickness and quality of the connecting steel plate, and also the thickness and quality of the connection bolts. The capacity of steel tensile connections as a result of capacity analysis and connection failure often has a lower value than the connection capacity in real conditions. In this research, the comparison of 30x30x3mm angle cross-section connections with BJ-37 quality was connected with $3 \mathrm{~mm}$ steel plate BJ-37 using 8 mm bolt connectors with A307 quality, through capacity analysis, failure study, and experimental study with type of bolt shear failure. In the capacity analysis study and the failure of steel tensile connections obtained a nominal capacity is $18.9 \mathrm{kN}$ with the type of shear failure. In the experimental study was tested 3 specimens, the average value of ultimit capacity was $22.63 \mathrm{kN}$ and the failure is bolt shear for all of the three specimens. The conclusion that can be drawn from this research is both the result of analytical calculations and experimental testing in the laboratory 
showed a good trend and the same. The test specimen was designed on the basis of analytical calculations for bolt shear failure, experimental test results for 3 (three) test specimens all showed a failure pattern of bolt shear. The nominal strength of the plan drag $\left(R_{n}\right)$ from the results of the analytical study with the ultimate load of the experimental study results has a difference of $16.48 \%$ with higher experimental results. Through this research is expected to be a learning-media to know one type of failure on the steel connections that is bolt shear failure, obtain a comparison of analytical calculation results referring to applicable planning standards and the results of experimental testing in the laboratory.

Keywords: Steel Tension Joint, Shear Failure, Experimental, Analytical, Capacity.

\section{PENDAHULUAN}

Struktur sambungan batang tarik baja memiliki kapasitas dengan macam-macam tipe kegagalan. Kapasitas sambungan batang tarik baja dapat ditentukan melalui analisis kapasitas dan kegagalan sambungan. Pada analisis kapasitas dan kegagalan sambungan batang tarik baja, kapasitas sambungan batang tarik baja yang ditentukan dihasilkan berdasarkan banyak parameter struktur diantaranya profil dan mutu batang tarik, tebal dan mutu pelat penyambung, dan terakhir tebal dan mutu baut sambungan. Kapasitas sambungan batang tarik baja hasil analisis kapasitas dan kegagalan sambungan seringkali memiliki nilai yang lebih rendah dari kapasitas sambungan dalam kondisi riil. Pada penelitian ini dilakukan perbandingan kapasitas sambungan batang tarik melalui studi analisis kapasitas dan kegagalan dan studi eksperimental dengan tipe kegagalan geser.

Tujuan penelitian adalah untuk mempelajari kapasitas kekuatan sambungan aksial batang tarik baja dengan metode analitis berdasarkan prediksi kapasitas kekuatan berdasarkan literature dan pengujian eksterimental di laboratorium.

Ruang lingkup penelitian yaitu benda uji yang ditinjau adalah sambungan aksial batang tarik, metode pembebanan adalah uniaksial tarik, jumlah benda uji adalah 3 (tiga) benda uji, pengujian menggunakan Universal Testing Machine di Laboratorium Struktur Universitas Kristen Maranatha, dalam perhitungan analitis digunakan asumsi tegangan leleh $\left(f_{y}\right)$ batang baja sebesar $240 \mathrm{MPa}$ dan tegangan ultimit $\left(\mathrm{f}_{\mathrm{u}}\right)$ batang baja sebesar 370 $\mathrm{MPa}$, kegagalan yang ditinjau adalah kegagalan geser pada alat sambung mekanik baut, profil batang baja yang ditinjau adalah siku L30.30.3, baut yang digunakan adalah baut biasa diameter 8 mm mutu A307..

\section{TINJAUAN PUSTAKA}

\subsection{Analisis Kekuatan Sambungan Batang Tarik Baja Menggunakan Baut}

Analisis kekuatan sambungan batang tarik baja menggunakan baut dilakukan berdasarkan SNI 1729:2015 "Spesifikasi untuk Bangunan Gedung Baja Struktural". 
Persamaan-persamaan yang harus dipenuhi menurut metode DFBK (Desain Faktor Beban dan Ketahanan) adalah sebagai berikut:

Kekuatan batang tarik menurut batas leleh pada penampang bruto sesuai SNI 1729:2015 Bab D2 (a) ditunjukkan dengan Persamaan 1.

$$
\phi \mathrm{R}_{\mathrm{n}}=\phi \times \mathrm{F}_{\mathrm{y}} \times \mathrm{A}_{\mathrm{g}}
$$

dengan:

$\mathrm{R}_{\mathrm{n}}=$ kuat nominal menurut batas leleh batang tarik

$\phi=$ faktor ketahanan kondisi batas leleh tarik, 0,90

$\mathrm{F}_{\mathrm{y}} \quad=$ tegangan leleh minimum material baja

$\mathrm{A}_{\mathrm{g}}=$ luas bruto penampang batang tarik

Kekuatan batang tarik menurut batas keruntuhan pada penampang neto sesuai SNI 1729:2015 Bab D2 (b) ditunjukkan dengan Persamaan 2.

$$
\phi \mathrm{R}_{\mathrm{n}}=\phi \times \mathrm{F}_{\mathrm{u}} \times \mathrm{A}_{\mathrm{e}}
$$

dengan:

$\mathrm{R}_{\mathrm{n}}=$ kuat nominal menurut batas keruntuhan batang tarik

$\phi=$ faktor ketahanan kondisi batas keruntuhan tarik, 0,75

$\mathrm{F}_{\mathrm{u}} \quad=$ tegangan putus minimum material baja

$\mathrm{A}_{\mathrm{e}} \quad=$ luas neto efektif penampang batang tarik

Luas neto efektif $\left(\mathrm{A}_{\mathrm{e}}\right)$ dihitung mengikuti ketentuan SNI 1729:2015 Bab D3, seperti pada Persamaan (3) dan Persamaan (4).

$$
\mathrm{A}_{\mathrm{e}}=\mathrm{U} \times \mathrm{A}_{\mathrm{n}}
$$

dengan:

$$
\mathrm{U} \quad=\text { faktor shear lag }
$$

$\mathrm{A}_{\mathrm{n}}=$ luas neto penampang batang tarik

Untuk penyaluran gaya tarik pada sambungan tidak melalui semua elemen penampang, perhitungan faktor shear lag $(\mathrm{U})$ :

$$
\mathrm{U}=1-\mathrm{x} / \mathrm{l}
$$

dengan:

$\mathrm{x} \quad=$ eksentrisitas sambungan

1 = panjang sambungan 
Luas neto penampang batang tarik $\left(\mathrm{A}_{\mathrm{n}}\right)$ dihitung mengikuti ketentuan SNI 1729:2015 Bab B4.3, yang dapat dituliskan seperti Persamaan (5).

$$
A_{n}=A_{g}-n_{\text {baut }} \times d \times t
$$

dengan:

$\mathrm{n}_{\text {baut }}=$ jumlah lubang baut pada garis potensial keruntuhan batang tarik

$\mathrm{d}=$ diameter lubang untuk perhitungan luas neto batang tarik, sesuai SNI 1729:2015 Bab B4.3 3b diambil 2mm lebih besar dari diameter nominal lubang baut. Diameter nominal lubang baut mengikuti ketentuan SNI 1729:2015 Bab J3.2 yaitu diameter baut $\left(\mathrm{d}_{\mathrm{b}}\right)+2 \mathrm{~mm}$ untuk $\mathrm{d}_{\mathrm{b}}<24 \mathrm{~mm}$

$\mathrm{t} \quad=$ tebal pelat dimana terdapat lubang

Kekuatan geser baut pada sambungan tipe tumpu, sesuai SNI 1729:2015 Bab J3.6 ditunjukkan dengan Persamaan 6.

$$
\phi \mathrm{R}_{\mathrm{n}}=\phi \times \mathrm{F}_{\mathrm{nv}} \times \mathrm{A}_{\mathrm{b}}
$$

dengan:

$\mathrm{R}_{\mathrm{n}}=$ kuat nominal geser baut

$\phi \quad=$ faktor ketahanan kondisi batas geser baut, 0,75

$\mathrm{F}_{\mathrm{nv}}=$ tegangan geser nominal baut

$\mathrm{A}_{\mathrm{b}}=$ luas nominal tubuh baut tidak berulir atau bagian berulir

Kekuatan tumpu lubang baut $\left(\phi \mathrm{R}_{\mathrm{n}}\right)$, sesuai SNI 1729:2015 Bab J3.10 (a) ditunjukkan dengan Persamaan 7.

$$
R_{n}=1,2 \times 1_{c} \times t \times F_{u} \leq 2,4 \times d_{b} \times t \times F_{u}
$$

dengan:

$\mathrm{R}_{\mathrm{n}}=$ kuat nominal tumpu pada lubang baut

$\phi \quad=$ faktor ketahanan kondisi batas tumpu 0,75

$1_{\mathrm{c}}=$ jarak bersih dalam arah gaya, antar tepi lubang baut

$\mathrm{t}=$ tebal material yang disambung, digunakan yang paling tipis

$\mathrm{d}_{\mathrm{b}} \quad=$ diameter baut

$\mathrm{F}_{\mathrm{u}} \quad=$ tegangan putus minimum material baja

Kekuatan geser blok $\left(\phi R_{n}\right)$ pada sambungan batang tarik baja, sesuai SNI 1729:2015 Bab J4.3 ditunjukkan dengan Persamaan 8.

$$
R_{n}=0,6 \times F_{u} \times A_{n v}+U_{b s} \times F_{u} \times A_{n t} \leq 0,6 \times F_{y} \times A_{g v}+U_{b s} \times F_{u} \times A_{n t}
$$

dengan: 
$\mathrm{R}_{\mathrm{n}} \quad=$ kuat nominal geser blok

$\phi \quad=$ faktor ketahanan kondisi batas geser blok, 0,75

$\mathrm{A}_{\mathrm{nt}} \quad=$ luas neto yang menahan tarik

$\mathrm{A}_{\mathrm{nv}} \quad=$ luas neto yang menahan geser

$\mathrm{A}_{\mathrm{gv}}=$ luas bruto yang menahan geser

$\mathrm{U}_{\mathrm{bs}} \quad=$ koefisien reduksi untuk perhitungan keruntuhan geser blok

$\mathrm{U}_{\mathrm{bs}}=1,0$ untuk tegangan tarik terdistribusi merata

$\mathrm{U}_{\mathrm{bs}}=0,5$ untuk tegangan tarik terdistribusi tidak merata

$\mathrm{F}_{\mathrm{u}} \quad=$ tegangan putus minimum material baja

\subsection{Pengujian Eksperimental Sambungan Batang Tarik Baja Menggunakan Baut}

Pengujian eksperimental tarik sambungan batang tarik baja didasarkan pada ASTM E8/E8M - 16a Standard Test Methods for Tension Testing of Metallic Materials (ASTM, 2016) dengan kecepatan mengujian chrosshead sebesar $0,015 \mathrm{~mm} / \mathrm{mm} / \mathrm{menit}$. Gambar 1 memperlihatkan Universal Testing Machine (UTM) yang digunakan untuk pengujian eksperimental.

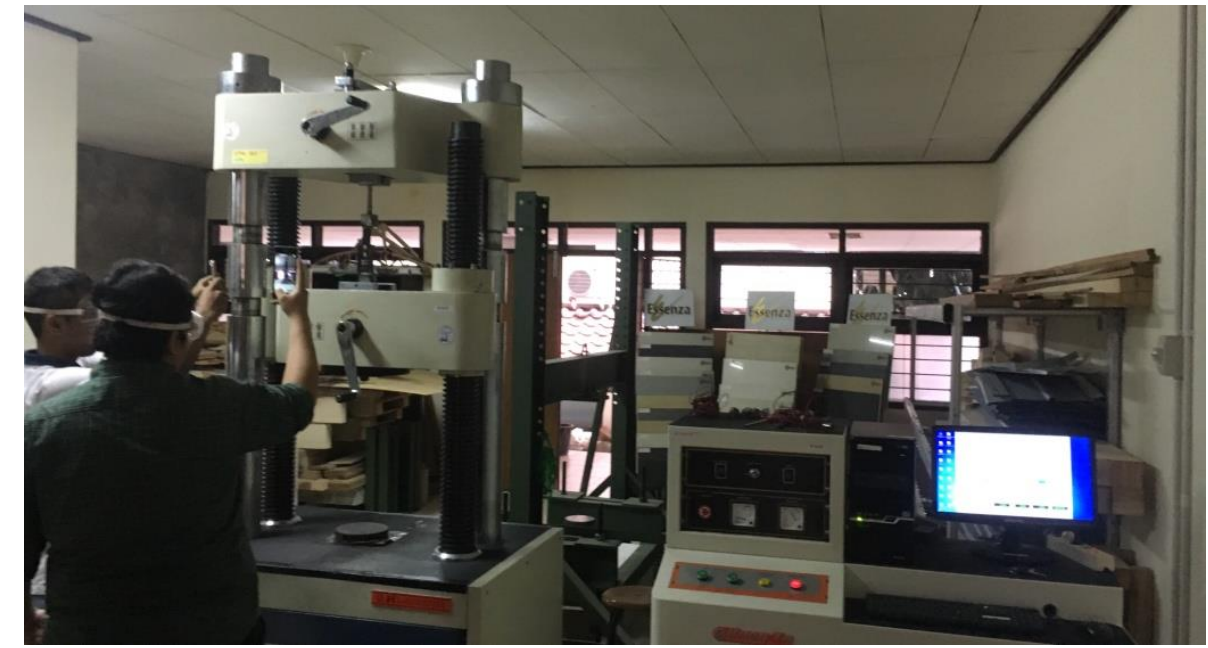

Gambar 1. Univeral Testing Machine untuk pengujian tarik sambungan baja

\section{STUDI KASUS}

Pada penelitian ini dilakukan pengujian batang tarik baja dari profil siku sama kaki mutu BJ-37 ukuran 30x30x3mm disambung dengan pelat baja mutu BJ-37 tebal $3 \mathrm{~mm}$ menggunakan baut mutu A307 diameter $8 \mathrm{~mm}$ yang memiliki konfigurasi sambungan seperti Gambar 2. 
Dengan konfigurasi sambungan batang tarik baja seperti terlihat pada Gambar 2, dilakukan dua model studi yaitu: studi analitis kekuatan sambungan batang tarik baja menggunakan baut menurut menurut metode DFBK yang ditentukan SNI 1729:2015 dan studi eksperimental pengujian sambungan batang tarik baja menggunakan baut di laboratorium.

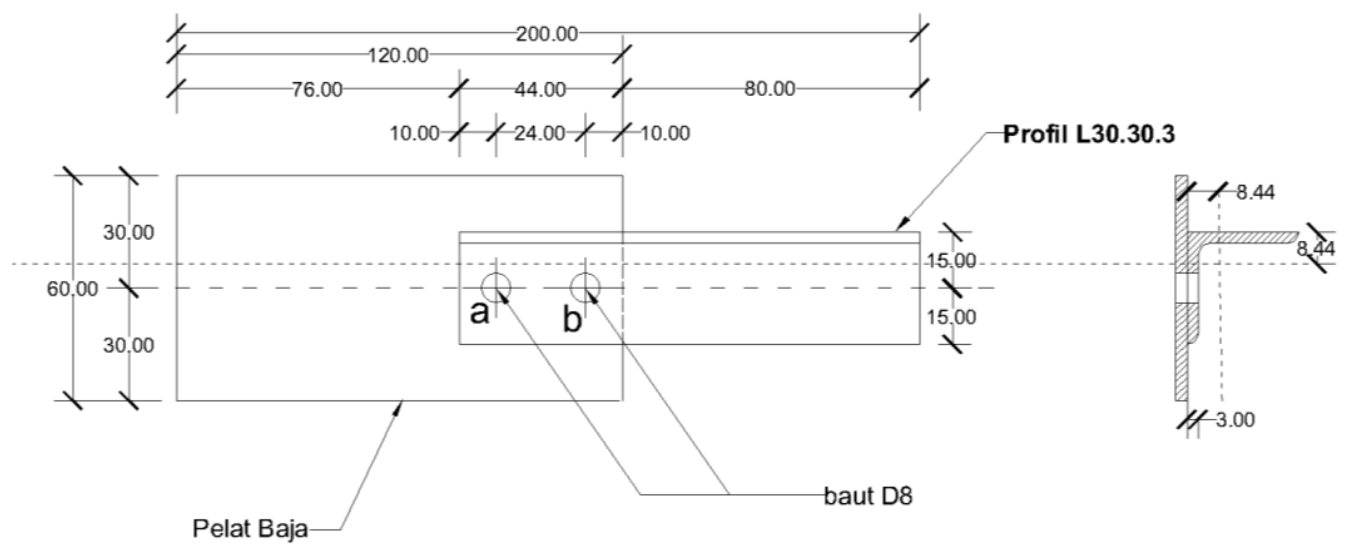

Satuan dalam $\mathrm{mm}$

Gambar 2. Konfigurasi Sambungan Pengujian Sambungan Batang Tarik Baja

\subsection{Studi Analitis Kekuatan Sambungan Batang Tarik Baja Menggunakan Baut}

Data profil siku L 30.30.3, mutu BJ-37:

$$
\begin{aligned}
\mathrm{B} & =30 \mathrm{~mm} \\
\mathrm{H} & =30 \mathrm{~mm} \\
\mathrm{~T} & =3 \mathrm{~mm}
\end{aligned} \quad \begin{aligned}
\mathrm{A}_{\mathrm{g}}=1,727 \mathrm{~cm}^{2} & \mathrm{~F}_{\mathrm{y}}=240 \mathrm{MPa} \\
\mathrm{C}_{\mathrm{y}}=0,844 \mathrm{~cm} & \mathrm{~F}_{\mathrm{u}}=370 \mathrm{MPa}
\end{aligned}
$$

Data pelat penyambung, mutu BJ-37:

$$
\mathrm{t}_{\mathrm{p}}=3 \mathrm{~mm} \quad \mathrm{~F}_{\mathrm{y}}=240 \mathrm{MPa} \quad \mathrm{F}_{\mathrm{u}}=370 \mathrm{MPa}
$$

Data baut penyambung, mutu A307:

$$
\begin{aligned}
& \mathrm{d}_{\mathrm{b}}=8 \mathrm{~mm} \\
& \mathrm{n}_{\text {baut }}=2
\end{aligned}
$$$$
\mathrm{A}_{\mathrm{b}}=50,27 \mathrm{~mm}^{2} \quad \mathrm{~F}_{\mathrm{nt}}=310 \mathrm{MPa} \quad \mathrm{F}_{\mathrm{nv}}=188 \mathrm{MPa}
$$

Kekuatan batang tarik profil siku menurut batas leleh dan batas keruntuhan dihitung menurut Persamaan 1 sampai Persamaan 5, diperoleh hasil sebagai berikut:

Kekuatan batang menurut kondisi batas leleh tarik:

$$
\begin{aligned}
\phi R_{n} & =0,90 \times F_{y} \times A_{g} \\
\phi R_{n} & =37303 N
\end{aligned}
$$

Kekuatan batang menurut kondisi batas keruntuhan tarik: 


$$
\begin{aligned}
\phi \mathrm{R}_{\mathrm{n}} & =0,75 \times \mathrm{F}_{\mathrm{u}} \times \mathrm{A}_{\mathrm{e}} \\
\mathrm{A}_{\mathrm{n}} & =\mathrm{A}_{\mathrm{g}}-\mathrm{n}_{\text {baut }} \times \mathrm{d} \times \mathrm{t}=172,7-1 \cdot(8+2+2) \cdot 3=136,70 \mathrm{~mm}^{2} \\
\mathrm{~A}_{\mathrm{e}} & =(1-\overline{\mathrm{x}} / \mathrm{l}) \mathrm{A}_{\mathrm{n}} \quad=(1-8,44 / 24) 136,70=88,63 \mathrm{~mm}^{2} \\
\phi \mathrm{R}_{\mathrm{n}} & =24594 \mathrm{~N}
\end{aligned}
$$

Kekuatan geser baut pada sambungan tipe tumpu dihitung menurut Persamaan 6, dengan hasil sebagai berikut:

Kekuatan geser sambungan yang menggunakan 2 buah baut:

$$
\begin{aligned}
& \phi \mathrm{R}_{\mathrm{n}}=0,75 \times \mathrm{n}_{\text {baut }} \times \mathrm{F}_{\mathrm{nv}} \times \mathrm{A}_{\mathrm{b}} \\
& \phi \mathrm{R}_{\mathrm{n}}=14175 \mathrm{~N}
\end{aligned}
$$

Kekuatan tumpu lubang baut dihitung sesuai Persamaan 7. Untuk perhitungan ini perlu ditentukan jarak bersih $\left(l_{c}\right)$ antar tepi lubang baut a ke tepi batang tarik yang disambung serta tepi lubang baut a dan baut b seperti ditunjukkan pada Gambar 3 .

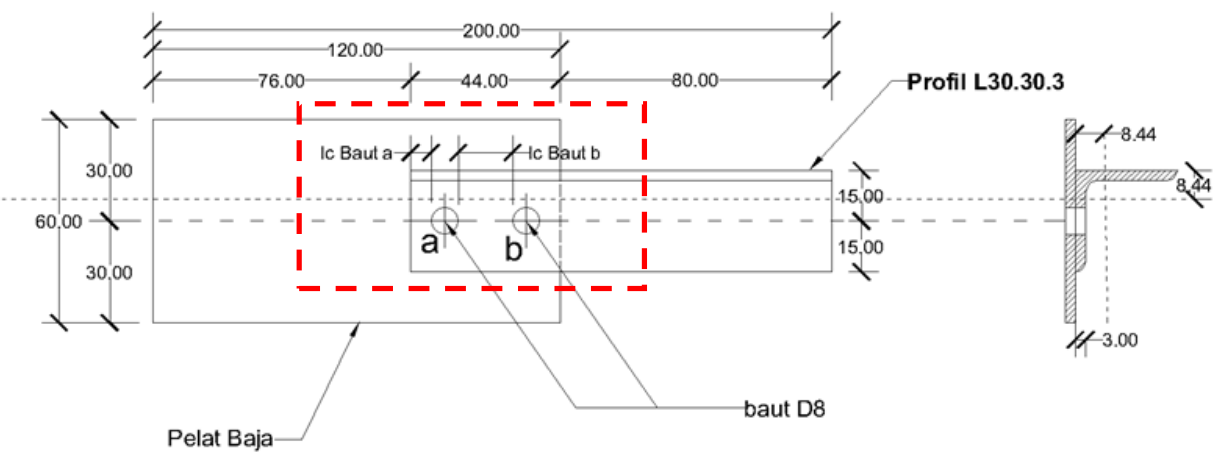

$\underset{\text { Satuan dalam } \mathrm{mm}}{\text { Scaiv: NTS }}$

Gambar 3. Penentuan jarak bersih $\left(l_{c}\right)$ antar tepi lubang baut

$$
\begin{array}{llll}
\mathrm{t}_{\text {profil }}=\mathrm{t}_{\text {pelat }} & =3 \mathrm{~mm} & 1_{\mathrm{c}} \text { baut a ke tepi profil } & =4 \mathrm{~mm} \\
\mathrm{~F}_{\mathrm{u}} & =370 \mathrm{MPa} & 1_{\mathrm{c}} \text { baut a dan baut } \mathrm{b}=12 \mathrm{~mm}
\end{array}
$$

Kekuatan tumpu lubang baut:

$$
\begin{aligned}
& \mathrm{R}_{\mathrm{n}}=1,2 \times \mathrm{l}_{\mathrm{c}} \times \mathrm{t} \times \mathrm{F}_{\mathrm{u}} \leq 2,4 \times \mathrm{d}_{\mathrm{b}} \times \mathrm{t}_{\mathrm{N}} \mathrm{F}_{\mathrm{u}} \\
& \text { baut a: } 5328 \leq 21312 \rightarrow \mathrm{R}_{\mathrm{na}}=5328 \mathrm{~N} \\
& \text { baut b: } 15984 \leq 21312 \rightarrow \mathrm{R}_{\mathrm{nb}}=15984 \mathrm{~N} \\
& \text { maka: } \quad \mathrm{R}_{\mathrm{n}}=\mathrm{R}_{\mathrm{na}}+\mathrm{R}_{\mathrm{nb}} \\
& \mathrm{R}_{\mathrm{n}}=21312 \mathrm{~N} \\
& \phi R_{n}=15984 \quad \mathrm{~N}
\end{aligned}
$$

Kekuatan geser blok sambungan batang tarik baja dihitung sesuai Persamaan 8 . Penentuan area geser blok ditunjukkan pada Gambar 4. 


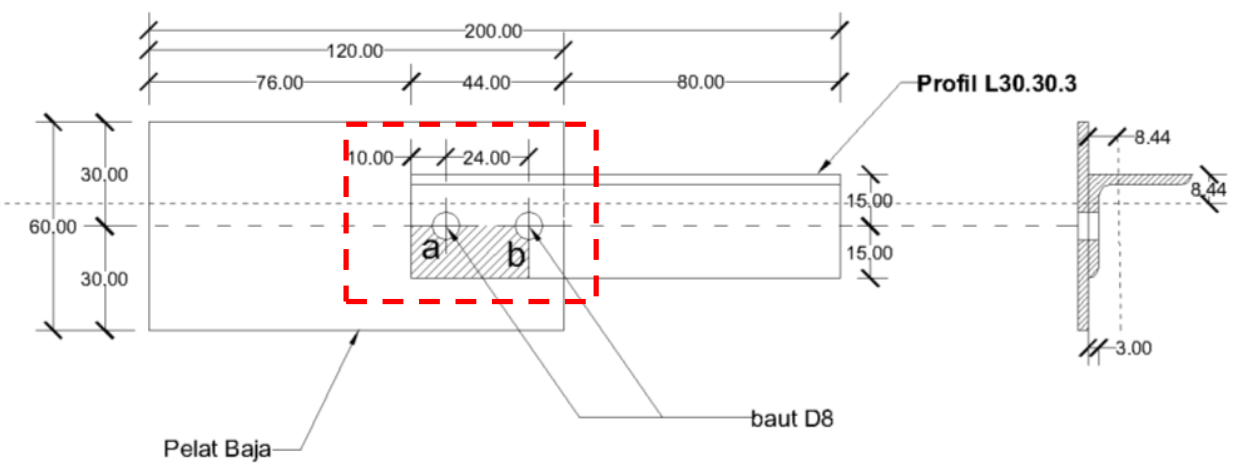

$\frac{\text { Satuan dalam mm }}{\text { Scaste: Nrs }}$

Gambar 4. Penentuan area geser blok pada sambungan batang tarik

Kekuatan geser blok:

$$
\begin{array}{cl}
\mathrm{R}_{\mathrm{n}}=0,6 \times \mathrm{F}_{\mathrm{u}} \times \mathrm{A}_{\mathrm{nv}}+\mathrm{U}_{\mathrm{bs}} \times \mathrm{F}_{\mathrm{u}} \times \mathrm{A}_{\mathrm{nt}} \leq 0,6 \times \mathrm{F}_{\mathrm{y}} \times \mathrm{A}_{\mathrm{gv}}+\mathrm{U}_{\mathrm{bs}} \times \mathrm{F}_{\mathrm{u}} \times \mathrm{A}_{\mathrm{nt}} \\
\mathrm{A}_{\mathrm{nv}}=(10+24-(3 / 2 \times 12)) \times 3 & =48 \mathrm{~mm}^{2} \\
\mathrm{~A}_{\mathrm{gv}}=(10+24) \times 3 & =102 \mathrm{~mm}^{2} \\
\mathrm{~A}_{\mathrm{nt}}=(15-1 / 2 \times 12) \times 3 & =27 \mathrm{~mm}^{2} \\
\text { Fraktur: } 0,6 \times \mathrm{F}_{\mathrm{u}} \times \mathrm{A}_{\mathrm{nv}}+\mathrm{U}_{\mathrm{bs}} \times \mathrm{F}_{\mathrm{u}} \times \mathrm{A}_{\mathrm{nt}} & =20646 \mathrm{~N} \\
\text { Leleh: } 0,6 \times \mathrm{F}_{\mathrm{y}} \times \mathrm{A}_{\mathrm{gv}}+\mathrm{U}_{\mathrm{bs}} \times \mathrm{F}_{\mathrm{u}} \times \mathrm{A}_{\mathrm{nt}} & =24678 \mathrm{~N}
\end{array}
$$

Nilai terkecil yang menentukan, sehingga $R_{n} \quad=20646 \mathrm{~N}$

$$
\phi \mathrm{R}_{\mathrm{n}} \quad=15485 \mathrm{~N}
$$

Rangkuman kapasitas sambungan batang tarik baja ditunjukkan pada Tabel 1, yaitu berdasarkan perhitungan analitis kapasitas kekuatan batas leleh tarik, kekuatan keruntuhan tarik, kekuatan geser sambungan baut, kekuatan tumpu lubang baut, dan kekuatan geser blok.

Tabel 1. Rangkuman Hasil Analisis Kapasitas Sambungan Batang Tarik Baja

\begin{tabular}{lccl}
\hline \multicolumn{1}{c}{ Analisis } & $\phi \mathbf{R}_{\mathbf{n}}(\mathbf{k N})$ & $\mathbf{R}_{\mathbf{n}}(\mathbf{k N})$ & Keterangan \\
\hline Kekuatan batas leleh tarik & 37,30 & 41,45 & \\
Kekuatan batas batas keruntuhan tarik & 24,59 & 32,79 & \\
Kekuatan batas geser sambungan & 14,18 & 18,90 & menentukan \\
Kekuatan batas tumpu lubang baut & 15,98 & 21,31 & \\
Kekuatan batas geser blok & 15,49 & 20,65 & \\
\hline
\end{tabular}

Dari studi analitis, konfigurasi sambungan batang tarik baja pada penelitian ini seperti yang terdapat pada Gambar 1 memiliki kuat batas sebesar 18,90 kN dengan kegagalan geser pada baut yang membatasi (tanpa faktor $\phi$ ). 


\subsection{Studi Eksperimental Sambungan Batang Tarik Baja}

Pada studi eksperimental pengujian sambungan batang tarik baja disiapkan 3 benda uji sesuai dengan konfigurasi Gambar 1. Pengujian tarik dilakukan dengan menggunakan Universal Testing Machine (UTM). Pada benda uji dilas penjepit khusus dari bahan Stainles Steel untuk memastikan sambungan baja menerima gaya aksial secara optimal seperti ditunjukkan pada Gambar 5.

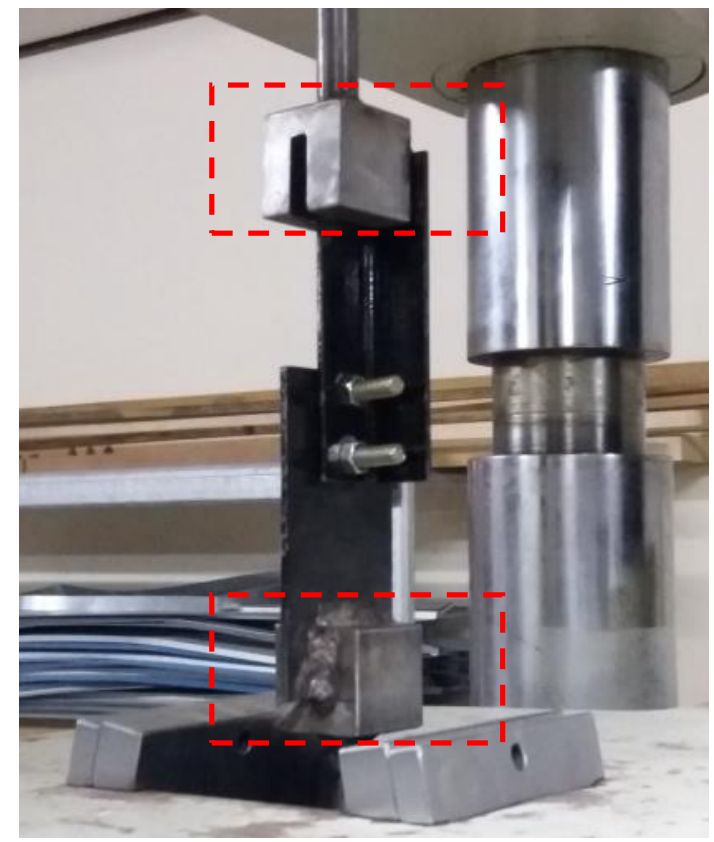

Gambar 5 Penjepit Khusus Benda Uji Sambungan Batang Tarik

Sebelum pengujian tarik dimulai, ketiga benda uji dilakukan ereksi pada baut agar semua elemen sambungan batang tarik baja dapat berkerja menerima beban secara optimal. Kondisi awal ketiga benda uji sambungan batang tarik baja ditunjukkan pada Gambar 6.

Setelah benda uji siap, dilakukan pengujian tarik pada masing-masing sambungan dengan kecepatan gaya aksial tarik sebesar $5 \mathrm{~mm} /$ menit hingga masing-masing benda uji mengalami kegagalan akibat gaya aksial tarik yang diterima. Hasil pengujian tarik pada setiap sambungan batang tarik baja ditunjukkan pada Gambar 7. 

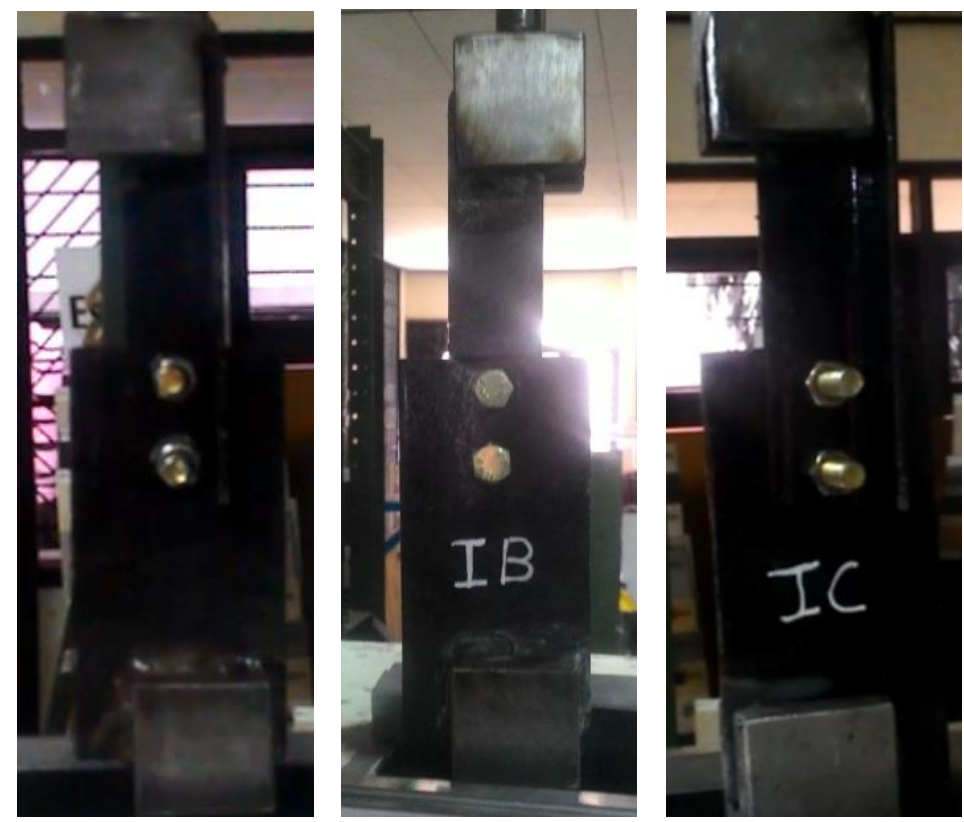

(a) Benda Uji 1

(b) Benda Uji 2

(c) Benda Uji 3

Gambar 6. Kondisi Awal Benda Uji Sambungan Batang Tarik Baja

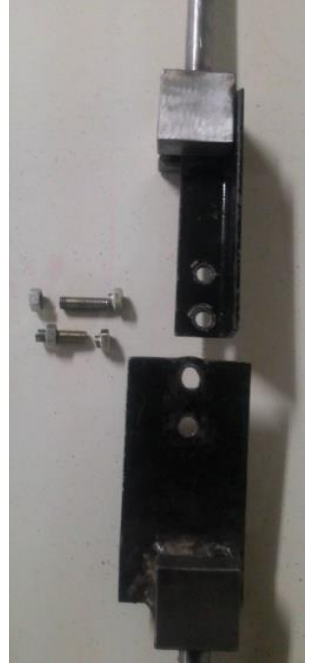

(a) Benda Uji 1

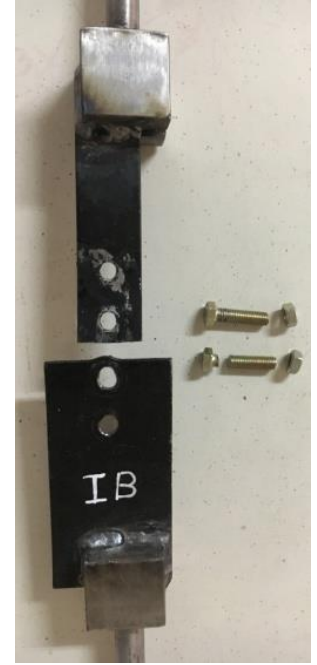

(b) Benda Uji 2

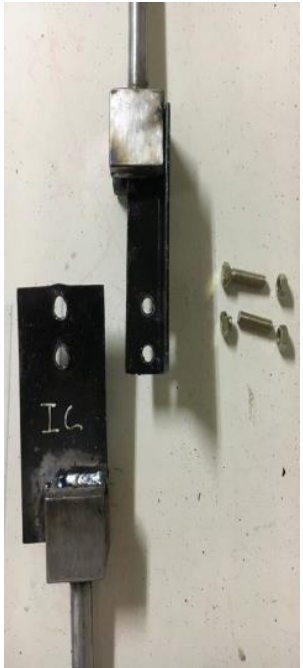

(c) Benda Uji 3

\section{Gambar 7. Hasil Pengujian Tarik Benda Uji Sambungan Batang Tarik Baja}

Pada Gambar 7, ketiga benda uji mengalami kegagalan geser pada baut sesuai dengan prediksi hasil studi analitis. Hasil pengujian tarik menggunakan Universal Testing Machine (UTM), didapatkan kurva beban terhadap deformasi (kurva P- D). Dari kurva P$\mathrm{D}$ diperoleh nilai beban batas proporsional $\left(\mathrm{P}_{\mathrm{y}}\right)$ dan nilai beban ultimit $\left(\mathrm{P}_{\mathrm{u}}\right)$ benda uji sambungan batang tarik baja yang ditunjukkan pada Gambar 8 dan Tabel 2 . 


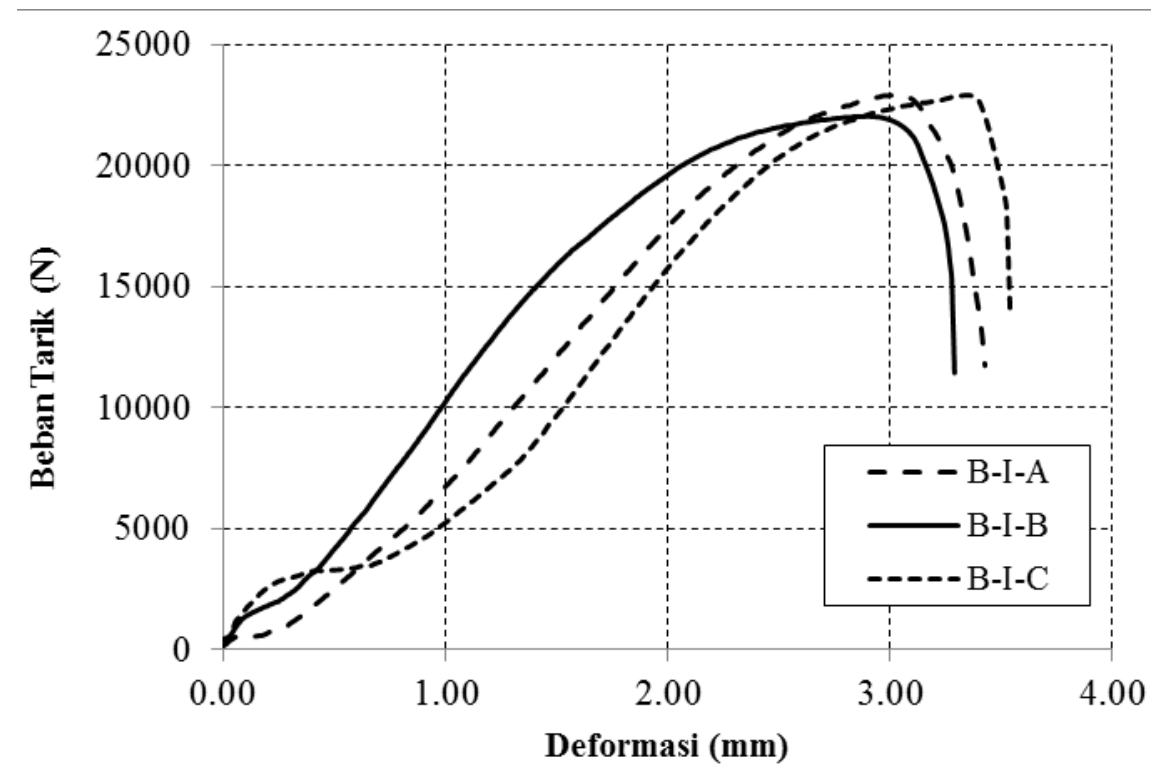

Gambar 8. Kurva P-D Benda Uji Sambungan Batang Tarik Baja

Tabel 2. Beban Batas Proporsional $\left(\mathbf{P}_{\mathbf{y}}\right)$ dan Beban Ultimit $\left(\mathbf{P}_{\mathrm{u}}\right)$ Benda Uji Sambungan Batang Tarik Baja

\begin{tabular}{ccccc}
\hline Benda Uji & $\mathbf{P}_{\mathbf{y}}(\mathbf{N})$ & $\mathbf{D}_{\mathbf{y}}(\mathbf{m m})$ & $\mathbf{P}_{\mathbf{u}}(\mathbf{N})$ & $\mathbf{D}_{\mathbf{u}}(\mathbf{m m})$ \\
\hline B-I-A & 19593,68 & 2,25 & 22928,38 & 3,03 \\
B-I-B & 19070,76 & 1,92 & 22047,70 & 2,91 \\
B-I-C & 20019,27 & 2,46 & 22910,28 & 3,30 \\
Rata-rata & 19561,24 & 2,21 & 22628,79 & 3,08 \\
\hline
\end{tabular}

Dari Tabel 2 diperoleh nilai rata-rata dari ketiga benda uji sambungan batang tarik baja. Untuk beban batas proporsional $\left(\mathrm{P}_{\mathrm{y}}\right)$ sebesar 19561,24 $\mathrm{N}$ dan untuk beban ultimit $\left(\mathrm{P}_{\mathrm{u}}\right)$ sebesar 22628,79 N.

Kuat batas desain $\left(\mathrm{R}_{\mathrm{n}}\right)$ dari hasil studi analitis sebesar $18,90 \mathrm{kN}$ atau $18900 \mathrm{~N}$ (tanpa faktor $\phi$ ). Jika dibandingkan dengan nilai beban ultimit dari hasil studi eksperimental $\left(\mathrm{P}_{\mathrm{u}}\right)$ rata-rata dari 3 (tiga) benda uji adalah sebesar 22628,79 $\mathrm{N}$ berarti hasil studi eksperimental memiliki nilai $16,48 \%$ lebih besar.

\section{KESIMPULAN}

Kesimpulan yang dapat diambil dari penelitian ini adalah sebagai berikut:

1. Studi analitis dan studi eksperimental sambungan batang tarik baja dengan konfigurasi sambungan seperti pada Gambar 2 menghasilkan kesimpulan yang sama untuk kondisi batas sambungan batang tarik yaitu kegagalan geser pada baut. Benda uji didesain berdasarkan perhitungan analitis untuk mengalami 
kegagalan geser pada baut, hasil pengujian eksperimental untuk 3 (tiga) benda uji seluruhnya menunjukkan pola kegagalan geser baut.

2. Kekuatan nominal tarik rencana $\left(R_{n}\right)$ dari hasil studi analitis dengan beban ultimit hasil studi eksperimental memiliki perbedaan sebesar 16,48 \% dengan hasil eksperimental lebih tinggi.

3. Melalui penelitian ini diharapkan dapat menjadi media pembelajaran untuk mengetahui salah satu jenis kegagalan pada sambungan batang tarik yaitu kegagalan geser baut, memperoleh gambaran perbandingan hasil perhitungan analtis yang mengacu pada standar perencanaan yang berlaku serta hasil pengujian eksperimental di laboratorium.

\section{DAFTAR PUSTAKA}

1. American Society for Testing and Material (2016), ASTM E8/E8M-16a Standard Test Methods for Tension Testing of Metallic Materials, American Society for Testing and Material.

2. Dewobroto,W., (2016), STRUKTUR BAJA Perilaku, Analisis \& Desain-AISC 2010 Edisi ke-2, Penerbit Jurusan Teknik Sipil UPH, Tangerang.

3. Badan Standardisasi Nasional, (2015), SNI 1729:2015 "Spesifikasi Untuk Bangunan Gedung Baja Struktural”, Badan Standardisasi Nasional, Jakarta. 